\title{
A Study on Locus of Control among College Students of Gulbarga City
}

\author{
Abdul Raffie Naik ${ }^{1}$
}

\section{ABSTRACT}

The current study focuses on locus of control and the difference in it among different demographic variables such as gender (male and female), course of study (science and arts) and locality (urban and rural) among college students. It is a promising area of inquiry. The age of college students is the age of developing their personality and is a critical context for studying personality. The study was conducted on 171 college student of Gulbarga city who were selected by a random sampling method (lottery method). The questionnaire consisted of personal data sheet, and Rotter's locus of control scale. Descriptive Statistics and non-parametric statistics as Mann-Witney test (U) were used to analyze the data. The results could not find significant difference on locus of control among males \& females, science \& arts and urban \& rural college students.

Keywords: Locus of control, Gender, locality, course of study

The concept "Locus of Control", was first developed by Julian B. Rotter. Locus of Control according to Rotter, refers to a personality dimension that helps explain one's behaviour. It refers to the perception the extent to which people believe that they can control the events that affect them, thus causing them to believe that they are the source of what happens in their life. Locus of control is defined as a person's tendency to see events as being controlled internally or externally (Rotter, 1966; Lloyd \&Hastinhs, 2009; French \&Shojaee, 2014). This tendency characterizes a person's perspective about self-independence and control by others (Corsini, 1999). Locus of Control also determines the likelihood of a particular behaviour as well as the outcomes of engaging in the behaviours (Lefcourt, 1976; April, Dharani, \& Peters, 2012: p. 125). People with internal locus of control feel that they can influence the outcomes of their work with their own efforts, skills and characteristics. People who perceive that outcome are determined by external forces like luck, chance and fate have an external locus of control orientation (Schultz \& Schultz, 2011).

${ }^{1}$ M.Sc. IV, Clinical and counselling psychology, Department of psychology, School of social and behavioural sciences, Central University of Karnataka

(c) 2015 I A Naik; licensee IJIP. This is an Open Access Research distributed under the terms of the Creative Commons Attribution License (http://creativecommons.org/licenses/by/2.0), which permits unrestricted use, distribution, and reproduction in any Medium, provided the original work is properly cited. 
People who have an internal locus of control tend to engage in adaptive behaviours (Demellow \& Imms, 1999; Peterson et al., 1993 \& Rothbaum et al., 1982, Hayadeh, 2004).

Since locus of control refers to the individuals' belief about controllability over what happens to them in life, it is defined as a personality trait or construct that reveals how individuals perceive their ability to control life events or environment (April et al., 2012). This belief can be characterized as one continuum on which two extremes can be recognized: internal locus of control and external locus of control.

\section{THE SIGNIFICANCE OF THE STUDY}

This study is significant because the study can provide the idea about the personality, which may helpto improve the existing services or create new services to help people to have more control in an environment where they usually feel out of control.

\section{METHODOLOGY OF THE STUDY}

This study is undertaken to make an attempt for understanding the Locus of Control among college students of Gulbarga city, along with the influence of demographic variables such as gender, place of residence and the course of study.

\section{OBJECTIVES:}

The study will be conducted with the following objectives:

1. To study the difference in Locus of control among male and female college students of Gulbarga city.

2. To study the difference in Locus of control among Arts and science college students of Gulbarga city.

3. To study the difference in Locus of control among Urban and Rural college students of Gulbarga city.

4. To study the level of locus of control among college students of Gulbarga city.

\section{HYPOTHESES:}

The study will be conducted with the following general hypotheses:

1. There would be a significant difference on locus of control among male and female college students.

2. There would be a significant difference on locus of control among science and arts college students.

3. There would be a significant difference on locus of control among rural and urban college students.

\section{Population:}

The population for the present study consists of students studying in different degree colleges of Gulbarga City which are affiliated to Gulbarga University and pursuing courses of 
B.A, B.Sc. the samples for the study are students of B.A and B.Sc. with the age range of $16-25$ years, studying in Gulbarga City Degree Colleges.

\section{Sampling technique:}

The samples were taken from different colleges of Gulbarga city which are affiliated to Gulbarga University. The colleges were selected by random sampling using the lottery method. There are 35 total colleges in city. The researcher had divided theses colleges in three categories based on courses selected for the study. First category consists of the college in which both arts and science courses are taught; in second category the colleges were selected in which science courses are taught and in third category the colleges were selected among which there are arts courses. Among the colleges which are having both science and arts streams the researcher had selected four colleges by lottery method and from the science stream college's two colleges were selected and two more from arts stream colleges. The data was collected from selected colleges by randomly choosing classes through lottery method. In some classes which were selected for data were large number of students. The researcher had chosen the sample among all odd roll numbers. Using this process, the researcher had collected data from 184 sample among which 171 were selected for final analysis. The remaining had incomplete information.

\section{Sources of the data:}

For the study, only primary data was used. The data required for the study was collected using questionnaires that were distributed among the sample chosen from the population that were the students studying in various colleges in Gulbarga.

\section{Inclusion criteria:}

$>$ The students who are studying in Degree College in Gulbarga city.

$>$ Those who are in the age range of 16- 25 years.

$>$ Those who can read write and communicate in English.

\section{Exclusion criteria:}

Students in Gulbarga city not studying B.A. and B.Sc.

\section{Assessment Tools:}

1. Rotter's Locus of Control Scale

\section{Description of tools:}

\section{Rotter's Locus of Control Scale:}

It is the Indian adaption of Julian Rotter's Internal-External scale by Dr.Anand Kumar and Dr. S.N. Srivastava of Kashi Vidyapith University, Varanasi. It measures an individual's perception of internal / external control of various events. This is a forced choice instrument 
which consists of 29 pairs of statements; each item has two sentence choices. Subject has to select one statement from each pair which he or she believes more strongly.

\section{Procedure:}

The participants were welcomed and rapport was established. The researcher gave brief information about the purpose of the study and informed consent had been taken from them. Each participant was reminded that their participation was completely voluntary, and that their responses would remain anonymous and reported only in aggregate form. And a request to fill up the demographic data sheet where information regarding their name, age, gender, education, and place. The participants were instructed to read the statement carefully and to select any option as their response from the scales. Participants completed a battery of self-report questionnaires including Locus of Control statement sheet. After completing the questionnaires, participants were debriefed and were thanked for their participation.

\section{Statistical Analysis:}

The present study had utilize quantitative techniques that includes descriptive statistics. Statistical Package for Social Sciences (SPSS) generates means, standard deviations, and frequencies for a list of variables, and non-parametric statistics were used for analysis which includes Mann-Witney test (U).

\section{RESULTS AND DISCUSSION}

Table: 1 Frequency distribution of demographic variables.

\begin{tabular}{llll}
\hline Demographic Variables & Category & Frequencies & Percent \\
\hline \multirow{2}{*}{ Sex } & Male & 89 & 52 \\
\cline { 2 - 4 } & Female & 82 & 48 \\
\hline Course & Science & 80 & 46.8 \\
\cline { 2 - 4 } & Arts & 91 & 53.2 \\
\hline \multirow{2}{*}{ Locality } & Urban & 94 & 55 \\
\cline { 2 - 4 } & Rural & 77 & 45 \\
\hline
\end{tabular}

Table 1 shows the distribution of demographic variables sex, course of study and locality in the present study the total number of participants were 171 under which there are 52\%(89) male and $48 \%(82)$ females. In course of study in science there are $46.8 \%(80)$ and under arts it is $53.2 \%$ (91). Locality participants under urban are 55\% (94) and under rural 45\% (77). 
Table: 2 Frequency distribution of Locus of control.

\begin{tabular}{llll}
\hline Variables & Category & Frequencies & Percent \\
\hline LOC & Internal & 115 & 67.3 \\
\cline { 2 - 4 } & External & 56 & 32.7
\end{tabular}

BDI: Beck depression inventory LOC: Locus of Control.

Table 2 shows the frequency distribution of variables under different categories. In locus of control 67.3\% (115) are internal locus of control and 32.7\% (56) falls under external locus of control.

Table: 3 Relationship of students' Locus of control on the basis of gender, (male and female)

\begin{tabular}{llllll}
\hline Variables & Category & Frequencies & Percent & Mann-Whitney U & Sig. \\
\hline \multirow{2}{*}{ Sex } & Male & 89 & 52 & & \\
\cline { 2 - 4 } & Female & 82 & 48 & 3619.500 & $.927^{\text {ns }}$ \\
\hline
\end{tabular}

${ }^{\mathrm{ns}}$ denotes non-significant.

While examining the Locus of control of college students, it is found that there was no significant difference between male and female students on the basis gender (Mann-Witney $\mathrm{U}=3619.500, \mathrm{p}>.05)$.

Table: 4 Relationship of students' Locus of control on the basis of course of study.

\begin{tabular}{llllll}
\hline Variables & Category & Frequencies & Percent & Mann-Whitney U & Sig. \\
\hline Course & Science & 80 & 46.8 & & \\
\cline { 2 - 4 } & Arts & 91 & 53.2 & 3054.500 & $.068^{\text {ns }}$ \\
\hline
\end{tabular}

ns denotes non-significant.

While examining the Locus of control of college students, it is found that there wasn't a significant difference between science and arts students on the basis of course of study (MannWitney $\mathrm{U}=3054.500, \mathrm{p}>.05)$.

Table: 5 Relationship of students' Locus of control on the basis of locality.

\begin{tabular}{llllll}
\hline Variables & Category & Frequencies & Percent & Mann-Whitney U & Sig. \\
\hline \multirow{2}{*}{ Locality } & Urban & 94 & 55 & & \\
& Rural & 77 & 45 & 3614.500 & $.989^{\text {ns }}$ \\
\hline
\end{tabular}

ns denotes non-significant.

While examining the Locus of control of college students, it is found that there was not a significant difference between rural and urban students based on locality (Mann-Witney $\mathrm{U}=3614.500, \mathrm{p}>.05)$. 


\section{DISCUSSION}

The current study focuses on locus of control and to study its differences within the demographic variables such as sex (male and female), course of study (science and arts) and locality (urban and rural).

\section{Hypothesis: 1}

“There would be a significant difference on locus of control among males and females”.

From the Table: 3, it is observed that, Mann Whitney-U value is not significant. Hence, this hypothesis is rejected and it could be concluded that there is no significant difference on Locus of Control among male and female college students.

Present study could not find any difference in Locus of Control of male and female college students. Mina Rastegar, NahidHeidari (2013) also concluded in their study that there were not any significant differences among males and females regarding to internal locus of control and external locus of control. Another study by Meghan Mole (2012) supports the findings of the current result that there is no statistically significant relationship found between Locus of control and gender. Lynton. N (2012) conducted a study in china, the findings does not show any significant relationship between locus of control and gender. In 2003 Dave Clarke also concluded in his findings that there were no significant differences between sexes on any mean score on locus of control. On the other side there are studies which are contradictory to the results of current funding's. Ghasemzadeh and Saadat (2011) concluded in their finding that female students for the locus of chance control received higher scores than the male students. Female students have more external locus of control than male (Parsons and Schneider 1974). Boys has internal locus of control and girls scored high on external locus of control (Zaidi and Mohsin 2013). Girls' means were supplementary external than boys' on LOC (Wehmeyer 1993).

\section{Hypothesis: 2}

“There would be a significant difference on locus of control among science and arts”.

Within this study it was expected that there would be significant difference on locus of control among science and arts. But from the Table: 4, it is observed that, Mann Whitney-U value is not significant. Hence, this hypothesis is rejected and it could be concluded that there is no significant difference on Locus of Control among science and arts college students.

Present study could not find any difference in Locus of Control of science and arts students. The researcher could not find studies to support the finding. As well as for contradictory. The factors which supports may be related to the exposure of the students in both the field's science as well as arts, and juvenility of the student's. So this study suggests that this area needs further research. 


\section{Hypothesis: 3}

“There would be a significant difference on locus of control among rural and urban”

From the Table: 5, it is observed that, Mann Whitney-U value is not significant. Hence, this hypothesis is rejected and it could be concluded that there is no significant difference in locus of control among rural and urban college students.

Present study could not find any difference on locus of control among rural and urban college students. The researcher could not find studies to support the finding. As well as for contradictory. The factors which supports may be related to the exposure of the students in both rural as well as in urban and juvenility of the student's. So this study suggests that this area needs further research.

\section{FINDINGS:}

1. Male and female college students do not differ in their Locus of Control.

2. Arts and Science college students do not differ in their Locus of Control.

3. Urban and Rural college students do not differ in their Locus of Control.

\section{CONCLUSION}

The study does not show any difference on the locus of controlamong male and female college students, science and arts college students, and urban and rural college students.

\section{RECOMMENDATIONS}

The researcher could not find any studies related to the relationship between locus of control with science and arts college students and urban and rural college students and relations between hopelessness with science and arts college students and urban and rural college students so it is suggested to do further research on such topics.

\section{REFERENCES}

April, K. A., Dharani, B., and Peters, K. (2012). Impact of Locus of Control Expectancy on Level of Well-Being. Review of European Studies Vol. 4, No. 2. 124 137.doi:10.5539/res.v4n2p124.

Burger, J. M. (1984). Desire for control, locus of control, and proneness to depression. Journal of personality 52:1 Duke University press;

Chioqueta, A. P., \& Stiles, T. C. (2005). Personality traits and the development of depression, hopelessness, and suicide ideation. Personality and Individual Differences, 1283-1291.

Cummings, J., \&Swickert, R. (2010). Relationship between locus of control and posttraumatic growth. Individual Differences Research, 8(3), 198-204. 


\section{A Study on Locus of Control among College Students of Gulbarga City}

Clarke, D. (2004). Neuroticism: moderator or mediator in the relation between locus of control and depression; journal Personality and Individual Differences 37 245-258.

Ghasemzadeh, A., \& saadat, M. (2011). Locus of control in Iranian university Student and it's relationship. Procedia - Social and Behavioral Sciences, 2491 - 2496.

Hillol, M., \& Poonam, M. (2014). Locus of control, birth Order and Residence as predictors of general wellbeing with special reference to Tripura. International Journal of Behavioral Research \& Psychology (IJBRP).

Jaswal, S., and Dewn, A. (1997). The relation between LOC and depression; Journal of personality and clinical studies vol 13 no 1-2 page 25-27.

Kolotkin, Richard A., And Others (1994). Sex Differences in Locus of Control, Helplessness, Hopelessness, and Depression; national seminar foundation; Washington.

Kurt, A., April, \&Ashridge. (2012). Impact of Locus of Control Expectancy on Level of WellBeing; journal Review of European Studies Vol. 4, No. 2;

Meghan, M. (2012). Satisfaction in Adult Romantic Relationships after Parental Divorce: The Role of Locus of Control. Natalie Hill.

Phares, E. J. (1976). Locus of control in personality. Morristown, New Jersey: General learning press.

Rastegar, M., \& Heidari, N. (2013). The Relationship between Locus of Control, Test Anxiety, and Religious Orientation among Iranian EFL Students. Scientific Research, 3, 73-78.

Ross, C. E., \&Mirowsky, R. (2002). Age and the gender gap in the sense of personal control. Social Psychology Quarterly, 65(2), 125-45.

Rotter, J. B., (1966). Generalized expectancies for internal versus external control of reinforcement. Psychological monographs, 80 (whole no. 609).

Rotter, J. B. (1975). Some problems and misconceptions related to the construct of internal versus external control of reinforcement. Journal of consulting and clinical psychology, 43, 65-67.

Wehmeyer, M. L. (1993). Gender differences in locus of control scores for students with learning disabilities. Percept Mot Skills, 77(2), 359-366.

Zaidi, I. H., \& Mohsin, M. N. (2013). Locus of Control in Graduation Students. International Journal of Psychological research, 15-20.

Zawawi, J. A., \&Hamaideh, S. H. (2009). Depressive Symptoms and Their Correlates with Locus of Control and Satisfaction with Life among Jordanian College Students;Europe's Journal of Psychology 4/2009, pp. 71-103 